Original Research Paper

\title{
Character Improvement of Red Rice (Oryza Sativa L.) Cv. Barak Cenana by Mutagenesis using Gamma Irradiation
}

\author{
Aloysia Sri Pujiyanti ${ }^{1}$, Bintang Kerta Wijaya ${ }^{1}$, Ida Bagus Made Artadana ${ }^{1^{*}}$, Popy \\ Hartatie Hardjo ${ }^{1}$, Maria Goretti Marianti Purwanto ${ }^{1}$ \\ ${ }^{1}$ Program Studi Magister Bioteknologi, Fakultas Teknobiologi, Universitas Surabaya
}

\author{
Article History \\ Received : March, $15^{\text {th }}, 2021$ \\ Revised : April 02 ${ }^{\text {th }}, 2021$ \\ Accepted : April 20"th 2021 \\ Published : May 03 ${ }^{\text {th }}, 2021$ \\ *Corresponding Author: \\ Ida Bagus Made Artadana, \\ Fakultas Teknobiologi, \\ Universitas Surabaya, \\ Indonesia \\ Email: $\underline{\text { arta@staff.ubaya.ac.id }}$
}

\begin{abstract}
Red rice cv. Barak Cenana is a local Indonesian rice which is widely planted in Tabanan Regency, Bali. Barak Cenana red rice has potential as a functional food because it contains a lot of nutrients. However, this rice has an unfavorable character, such as long harvest time so that it can only be harvested once a year, and tall stature that causes plants to lodge easily, reducing its productivity. This study aims to determine the effect of gamma rays on growth and development as well as changes in character to obtain mutants plants that have better character. In this research, Barak Cenana seeds were irradiated using gamma rays with irradiation doses of $100 \mathrm{gy}, 200 \mathrm{gy}, 400 \mathrm{gy}$, and 800 gy. Furthermore, radiated seeds were planted in the greenhouse and characterized during the vegetative and generative phases including shoot length, harvest time, chlorophyll content, the number of productive tillers, the number of grain contents, the weight of 1,000 seeds, and the polymorphism profile using Random Amplified Polymorphic DNA Analysis (RAPD). The results of this study indicate that all radiation doses produce plants with random characters. Mutations using gamma rays at doses of $100 \mathrm{gy}$ and $400 \mathrm{gy}$ produced plants with better phenotypic characters than wild-type that is shorter plants, shorter harvest times, and more grain content. In addition, the results of the RAPD analysis confirm that there are genetic changes in irradiated rice. This mutants has the potential to reproduce germplasm and to obtain the next generation of mutants that have higher productivity and shorter plant heights.
\end{abstract}

Keywords: Gamma irradiation, induced mutation, Barak Cenana (Oryza sativa $\mathrm{L}$. .), RAPD.

\section{Pendahuluan}

Beras adalah makanan pokok yang dikonsumsi oleh lebih dari separuh umat manusia di dunia dan diprediksi meningkat di masa depan. Manusia memanfaatkan beras sebagai sumber energi karena mengandung karbohidrat dalam jumlah besar (Mohanty, 2013; USDA, 2013). Tapi pada dewasa ini manusia mencari manfaat lain dari beras/nasi seperti antioksidan, aroma, tekstur dan lain lain (Gunaratne et al., 2013; Zhang et al., 2010). Banyak jenis dan varietas beras beredar di pasaran dengan berbagai karateristik yang ditumbuhkan secara lokal di daerah-daerah tertentu seperti padi beras putih, merah, atau hitam. Padi Barak Cenana merupakan padi merah varietas lokal yang ditanam secara turun temurun oleh petani di kecamatan Penebel, Kabupaten Tabanan-Bali.

Padi Barak Cenana termasuk dalam komoditi yang memiliki nilai tinggi karena mengandung vitamin $\mathrm{B}$ dan antioksidan seperti antosianin yang diketahui mampu menghindari penyakit degeneratif dan menunda penuaan pada manusia, oleh karena itu padi Barak Cenana dapat dimanfaatkan sebagai bahan pangan fungsional (Widarta et al, 2013). Padi Barak Cenana sendiri saat ini jarang dibudidayakan petani di Indonesia karena umur tanam yang panjang yaitu 185 hari dibandingkan dengan padi beras putih unggul yang memiliki umur genjah 105 hari. Padi merah Barak Cenana dapat tumbuh hingga tinggi $190 \mathrm{~cm}$ atau dengan rata-rata 
panjang tanaman $160 \mathrm{~cm}$, tergolong tinggi bagi tanaman padi. Akibatnya, batang mudah patah terutama pada fase reproduksi, sehingga kemudian menyebabkan padi rebah dan petani mengalami penurunan hasil panen (Silitonga, 2015). Oleh karena itu, perlu suatu usaha untuk memperbaiki karakter dari padi merah Barak Cenana tersebut agar dapat memiliki karakter yang unggul sehingga dapat meningkatkan minat petani untuk membudidayakan padi merah ini dan meningkatkan minat masyarakat untuk mengkonsumsi padi Barak Cenana ini.

Salah satu cara yang dapat dilakukan untuk memperbaiki karakter padi merah Barak Cenana yaitu dengan melalui pemuliaan tanaman dengan mutasi secara fisik yang dapat dilakukan dengan iradiasi sinar radioaktif, misalnya sinar gama (Rajarajan et al., 2014). Strategi pemuliaan menggunakan mutasi digunakan dalam situasi dimana kultivar dapat ditingkatkan secara signifikan dengan modifikasi suatu sifat dari tanaman atau memunculkan sifat/genotip baru. Radiasi sinar gama mampu memutus struktur DNA yang kemudian menyebabkan urutan sekuennya dapat berubah hal ini lah yang menyebabkan ekspresi/fenotipik yang dihasilkan bisa berbeda dengan Wild Type (Hanafy dan Akladious, 2018). Adapun mutasi induksi pada tanaman padi untuk memperoleh sifat unggul telah banyak dilakukan, seperti pada padi Ciherang, padi Cempo, padi Hitam lokal dan padi Mentik Susu yang dimutasi menggunakan sinar gama dengan dosis radiasi antara 200 gy hingga 300 gy memiliki karakteristik unggul produktivitas yang lebih tinggi, kadar protein yang lebih baik, tanaman yang lebih pendek, kadar amilosa rendah dan lama panen yang lebih cepat (Masruroh et al., 2016; Aprida dan Yuwono, 2017; Rachmawati et al., 2019). Belum ada penelitian untuk memperbaiki sifat padi Barak Cenana menggunakan sinar gama, sehingga pada penelitian ini dilakukan radiasi pada biji padi dengan dosis 100,200 , 400, dan 800 gy.

Penilaian berbasis morfologi seringkali menyebabkan terjadinya kesalahan dalam proses seleksi mutan, karena fenotip kurang mewakili tingkat diversitas genetik mutan: sifat yang tampak sangat tergantung ekspresi gen dan faktor lingkungan (Bibi, et al., 2009). Oleh sebab itu digunakan metode Random Amplified Polymorphic DNA Analysis (RAPD), teknik berbasis PCR ini menggunakan primer yang mampu mendeteksi polimorfisme tanpa diperlukannya informasi sekuens nukleotida spesifik untuk melihat genotip dari mutan dibandingkan Wild Type (Bhuiyan et al., 2019). Teknik RAPD sendiri sudah banyak dilakukan untuk mengetahui kekerabatan/perbedaan secara genetik pada pemuliaan tanaman tanaman padi (Bhuiyan et al., 2019; Naeem et al., 2015; dan Masood et al., 2015).

\section{Bahan dan Metode}

Penelitian dilaksanakan di Laboratorium Bioteknologi Tanaman dan Laboratorium Biologi Molekuler dan Purifikasi Fakultas Teknobiologi Universitas Surabaya pada bulan Januari 2018-Januari 2019. Bahan tanaman yang digunakan ialah benih padi Barak Cenana (Oryza sativa L.) yaitu sebanyak 400 biji, dimana 100 biji per perlakuan dosis sinar gama. Benih padi Barak Cenana yang memiliki karakteristik baik diradiasi dengan menggunakan sinar gama dengan lama waktu tertentu hingga dosis penyinaran yang tertera pada dosimeter sebesar 100 gy, 200 gy, 400 gy dan 800 gy. Radiasi dengan sinar gama dilakukan di Badan Tenaga Nuklir Nasional.

\section{Germinasi benih padi hasil mutasi dan pemeliharaan tanaman}

Biji padi hasil mutasi digerminasi dengan diletakkan pada tisu yang telah dibasahi dengan akuades di dalam cawan petri dan diinkubasi selama 7 hari. Biji padi yang telah berkecambah dipindahkan ke plastic tray dengan perbandingan media tanah: pupuk organik adalah 1:1 dan diletakkan dalam kolam buatan. Setelah muncul 5 daun, tanaman padi ditransfer dari plastic tray ke pot plastik (diameter $25 \mathrm{~cm}$ dan tinggi $22 \mathrm{~cm}$ ) dengan perbandingan komposisi media tanah : pupuk organik yaitu 1:1. Pot plastik diletakkan dalam kolam buatan dan diberi pupuk anorganik N, P, K (5 gram) dan pupuk organik setiap 2 minggu sekali. Padi yang tumbuh diamati dan dicatat morfologi yang nampak meliputi ukuran 
kecambah, tinggi tanaman, jumlah anakan, lama waktu panen, jumlah anakan produkif, dan jumlah gabah isi dan gabah kosong serta berat $1.000 \mathrm{biji}$

\section{Ekstraksi dan Kuantifikasi Kadar Klorofil pada Daun Padi}

Daun segar padi merah Barak Cenana dihaluskan dan ditambahkan aseton $5 \mathrm{ml}$ untuk $50 \mathrm{mg}$ sampel. Inkubasi selama 72 jam dan dianalisa dengan spektrofotometer UV/Vis dengan panjang gelombang 665 dan $646 \mathrm{~nm}$ (Barnes et al., 1992; Wellburn et al. 1994). Kadar klorofil A dan B dihitung menggunakan rumus :

$[\mathrm{Kla}]=12,58$ A665 - 2,93 A646

$[\mathrm{Klb}]=21,14$ A646 - 5,09 A665

Total Klorofil = 7,49 A665 + 18,21 A646

\section{Isolasi DNA dan Analisa Genotipik dengan Metode RAPD}

Isolasi DNA Padi Barak Cenana diambil dari sampel daun pertama setelah daun bendera pada akhir fase generatif yang kemudian dilakukan ekstraksi DNA total Padi menggunakan Plant Genomic DNA KIT TIANGEN. Hasil isolasi DNA total Padi Barak Cenana kemudian dilakukan analisis genotipik dengan menggunakan metode PCR RAPD. Analisis PCR dilaksanakan dalam campuran bervolume total $15 \mu$, meliputi $1 \mathrm{X}$ unit reaksi PCR Mix, 20 ng template DNA genomik, dan 0,1 $\mathrm{mM}$ primer. Sampel DNA diamplifikasi menggunakan mesin siklus termal (mengikuti program yang telah didapatkan dari proses optimasi: pertama pada suhu $95^{\circ} \mathrm{C}$ selama 5 menit kemudian diikuti 35 siklus, selama 1 menit pada suhu $94^{\circ} \mathrm{C}$, lalu diikuti suhu annealing $36^{\circ} \mathrm{C}$ selama 1 menit, kemudian 1 menit pada $72^{\circ} \mathrm{C}$, dan tahapan akhir untuk finalisasi ekstensi di akhir siklus ke 45 selama 5 menit pada $72^{\circ} \mathrm{C}$. Primer yang digunakan adalah OPA-10 (GTGATCGCAG), OPA-13 (CAGCACCCAC), OPE-01 (CCCAAGGTCC), dan OPF-13 (GGCTGCAGAA).

Elektroforesis gel dilakukan dengan memasukkan produk amplikon ke sumur gel 2,5\% agarosa dalam $1 \mathrm{X}$ Tris asetat EDTA (TAE) buffer. Penggaris molekular DNA 100 bp dimasukkan sebagai acuan skala panjang fragmen amplikon. Elektroforesis dilakukan dengan parameter $100 \mathrm{~V} / \mathrm{cm}$ selama \pm 1 jam. Gel diwarnai dengan etidium bromida $0,5 \mu \mathrm{g} / \mathrm{ml}$ dan difoto menggunakan kamera sistem dokumentasi gel diatas lampu UV (Deshmuskh et al., 2007).

\section{Analisa Data}

Rancangan penelitian yang digunakan yaitu Rancangan Acak Lengkap dengan 4 perlakuan dosis penyinaran sinar gama dimana setiap perlakuan terdapat 100 biji padi. Adapun data-data yang bersifat kuantitatif yaitu data hasil pengamatan morfologi atau fenotip tanaman mutan akan dianalisa dengan ANOVA One-Way (Analyisis of Variance) dengan uji lanjut Duncan Multiple Range Test (DMRT) dengan taraf $\alpha=5 \%$ menggunakan software IBM SPSS Statisstic 20 dimana data terlebih dahulu diuji dengan Normality Test untuk menentukan apakah data tersebut berdistribusi normal. Apabila data tidak berdistribusi normal maka pengujian dilakukan dengan metode non-parametrik Kruskall-Wallis Test.

Analisis data molekuler dilakukan menggunakan bantuan perangkat lunak berbasis Phyton, PyElph versi 1.4 (Pavel \& Vasile, 2012) dan PAST (Paleontological Statistic) (Hammer et al. 2001). Hasil yang dianalisis adalah fragmenfragmen amplikon yang terlihat jelas. Luaran yang dihasilkan berupa berkas teks berisi matriks yang terdiri dari angka nol dan satu. Dilakukan pembuatan dan penomoran gugus polimorfisme berdasarkan skor 1 dan 0 menggunakan perangkat lunak Microsoft Excel. Nilai PIC dihitung dengan rumus sebagai berikut:

$$
P I C=2 f i(1-f i)
$$

\section{Hasil dan Pembahasan}

\section{Perkecambahan Padi Merah Cv. Barak Cenana}

Semua benih berhasil berkecambah, dengan ditandai tumbuhnya koleoptil dan akar pada semua benih, meski demikian bibit padi yang teradiasi mengalami perlambatan pertumbuhan dimana semakin bear dosis radiasi maka ukuran kecambah semakin pendek (Gambar 1). Selain itu, pengukuran panjang tunas pada hari ke-7 setelah tanam (Tabel 1) pada benih yang diradiasi 400 dan 800 gy menimbulkan dampak negatif untuk pertumbuhan tunas pada padi Barak Cenana. Terbukti dengan perbedaan secara signifikan pada pertumbuhan tunas padi barak cenana yang 
berumur 7 hari, dimana pertumbuhan ukuran kecambah padi mengalami perlambatan dibandingkan dengan kontrol.

Tabel 1. Pengaruh Berbagai Konsentrasi Sinar Gama Terhadap Ukuran Kecambah Padi Barak Cenana pada Hari Ke-7 HST

\begin{tabular}{cc}
\hline Perlakuan & Panjang Tunas $(\mathrm{cm})$ \\
\hline Wild Type & $5,458 \mathrm{a} \pm 0,297$ \\
100 gy & $4,717 \mathrm{~b} \pm 0,532$ \\
200 gy & $3,358 \mathrm{c} \pm 1,164$ \\
400 gy & $0,558 \mathrm{~d} \pm 0,193$ \\
800 gy & $0,300 \mathrm{~d} \pm 0,128$ \\
\hline
\end{tabular}

Keterangan: Uji ANOVA One-Way pada $\alpha=5 \%$, Uji $D M R T$ pada $\alpha=5 \%$. Angka yang diikuti huruf yang sama pada kolom yang sama menunjukkan hasil yang tidak berbeda nyata $(\mathrm{P}>0,05)$.

\section{Karakter Fenotipik Padi Merah Mutan Cv. Barak Cenana}

Dari 10 gelombang penanaman dengan tiap gelombang penanaman ditanaman $10 \mathrm{biji}$ padi untuk tiap perlakuan, terdapat 14 tanaman yang berhasil tumbuh hingga panen. Dosis 100 gy menghasilkan 5 tanaman meliputi A3, A5,
A14, A19, dan A25. Dosis 200 gy menghasilkan 8 tanaman meliputi B13, B15, B17, B18, B19, B20, B24, dan B34. Dosis 400 gy menghasilkan satu tanaman yaitu C6.

Pada pengamatan kelompok (Tabel 2) tidak menunjukkan perbedaan antara kontrol dan hasil mutan fenotipik pada masa vegetatif dan reproduktif. Pada pengamatan individu teramati adanya 2 individu dengan karakter ekstrim/unik yaitu pada dosis 400 dan 100 gy. Dimana pada dosis 400 gy meskipun hanya satu tanaman yang mampu tumbuh hingga panen, tanaman ini memiliki karakter yang cukup unik yaitu jumlah gabah isi yang banyak yaitu C6. Serta ditemukan tanaman yang memiliki tinggi pendek dan waktu panen yang lebih cepat yaitu A3 pada pengamatan individu (Tabel 3) (Gambar 2).

Dari hasil analisa kadar klorofil (Tabel 4) didapati bahwa pada tanaman A3 dan C6 memiliki kadar klorofil baik A dan B yang lebih besar secara signifikan dibanding WT.
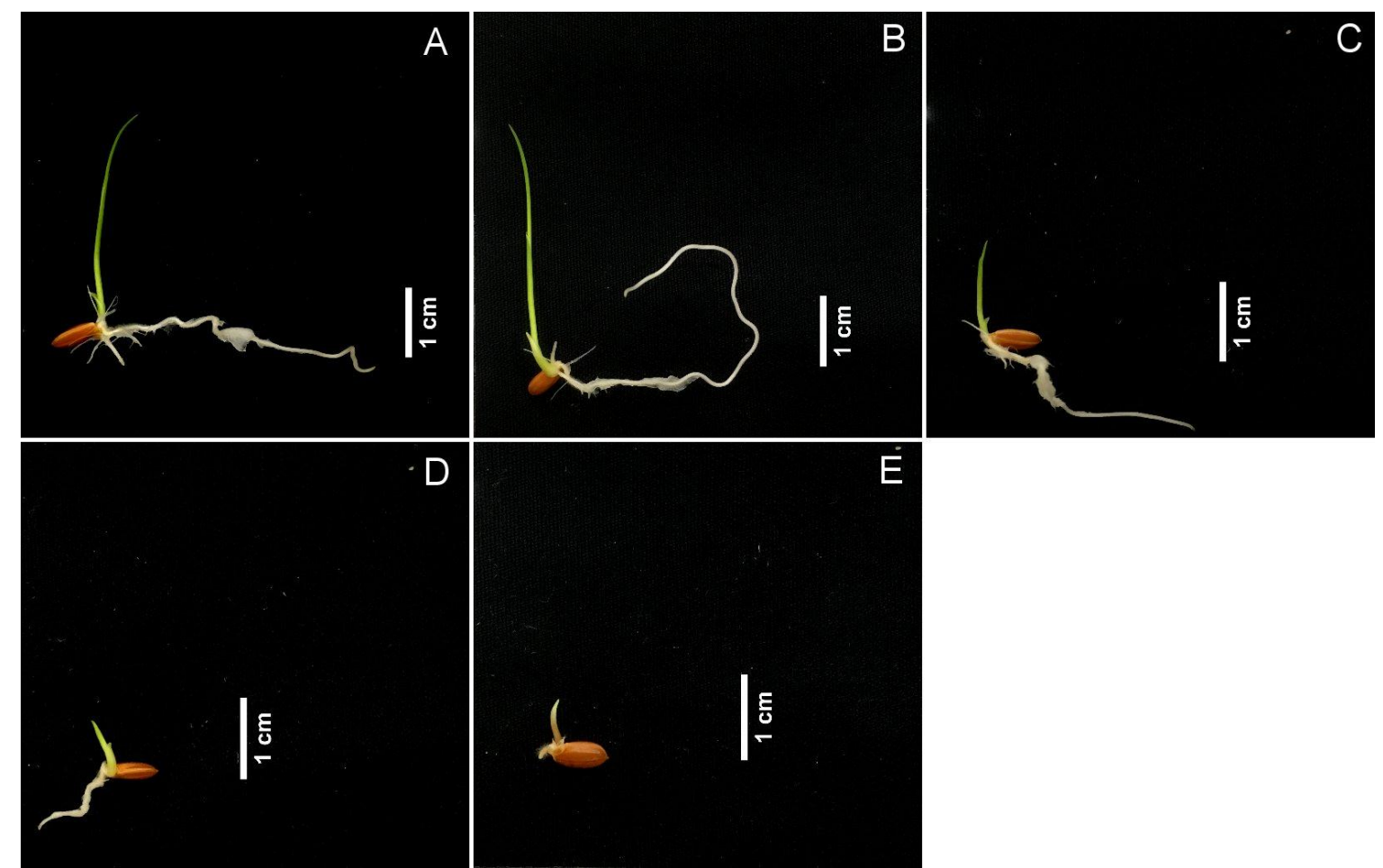

Gambar 1. Pertumbuhan Kecambah pada Hari Ke-7 Hasil Mutasi Sinar Gama. Keterangan: (A) Wild Type, (B) 100 gy, (C) 200 gy, (D) 400 gy, (E) 800 gy. Bar Skala = $1 \mathrm{~cm}$ 


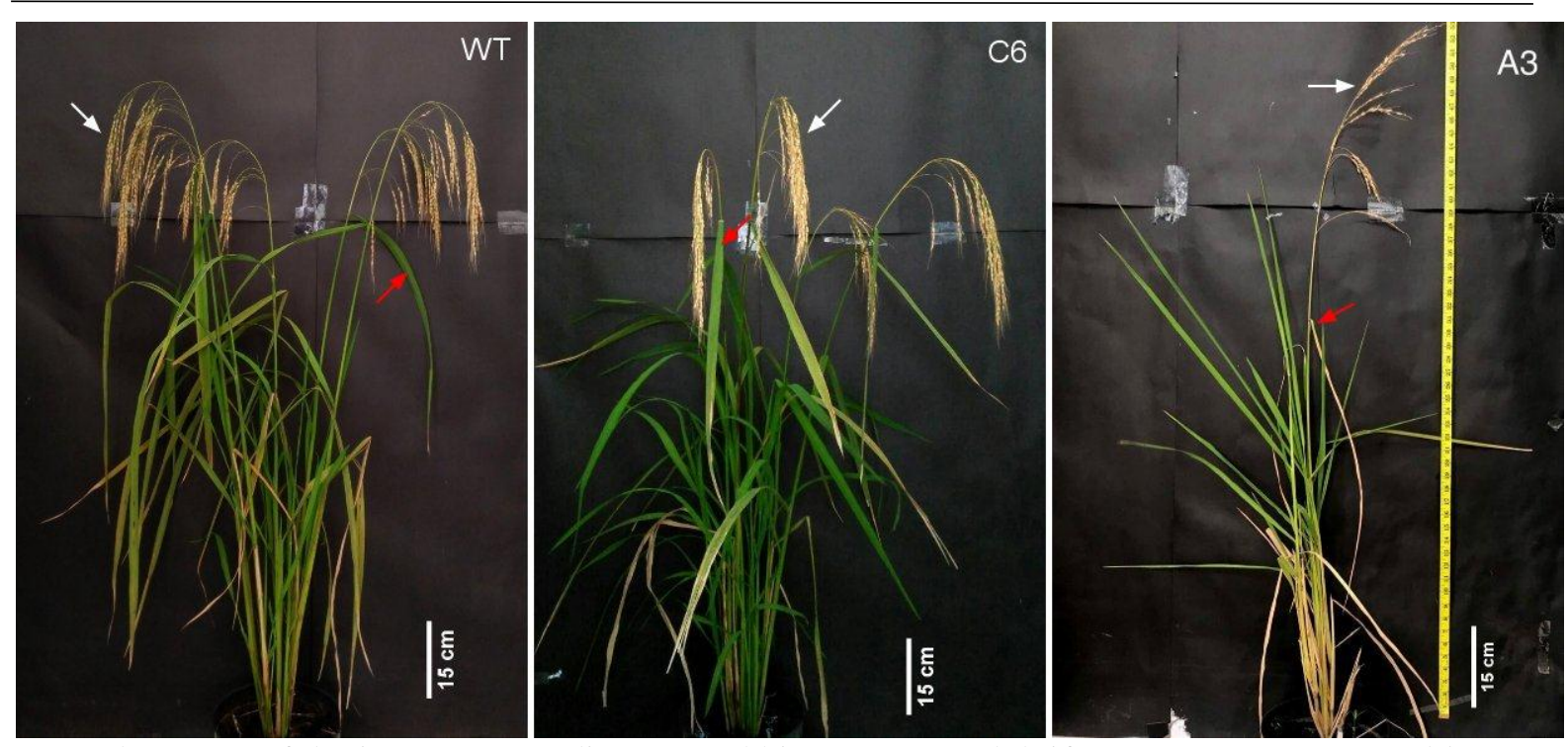

Gambar 2. Morfologi Tanaman Padi Mutan Akhir Fase Reproduktif. Keterangan: (WT) Wild-type;

(A3) Individu Mutan A3 100 gy, (C6) Individu Mutan C6 400 gy, (Panah merah) Daun Bendera,

(Panah Putih) Malai. Bar Skala $=15 \mathrm{~cm}$

Tabel 2. Karakter Agronomi Padi Merah Cv. Barak Cenana yang Termutasi dengan Sinar Gama

\begin{tabular}{ccccc}
\hline Variabel & \multicolumn{4}{c}{ Dosis Radiasi Sinar Gama } \\
\cline { 2 - 5 } Pengamatan & Wild Type & $100 \mathrm{gy}$ & $200 \mathrm{gy}$ & $400 \mathrm{gy} *$ \\
\hline Tinggi $(\mathrm{cm}) * *$ & $152,50 \mathrm{a} \pm 5,57$ & $135,60 \mathrm{~b} \pm 16,83$ & $148,88 \mathrm{ab} \pm 6,38$ & 150,00 \\
Jumlah Anakan*** & $11,25 \mathrm{a} \pm 3,30$ & $10,40 \mathrm{a} \pm 2,70$ & $8,86 \mathrm{a} \pm 3,00$ & 10,00 \\
Jumlah Anakan Produktif** & $7,25 \mathrm{a} \pm 2,50$ & $6,40 \mathrm{a} \pm 3,36$ & $5,50 \mathrm{a} \pm 1,60$ & 6,00 \\
Jumlah Gabah Isi (biji)** & $530,00 \mathrm{a} \pm 434,36$ & $164,60 \mathrm{~b} \pm 135,17$ & $289,88 \mathrm{ab} \pm 136,67$ & 1044,00 \\
Jumlah Gabah Kosong (biji)*** & $430,75 \mathrm{a} \pm 220,53$ & $365,40 \mathrm{a} \pm 246,04$ & $313,63 \mathrm{a} \pm 166,49$ & 208 \\
Persentase Gabah Isi (\%)** & $49,79 \mathrm{a} \pm 13,88$ & $32,15 \mathrm{a} \pm 17,76$ & $48,27 \mathrm{a} \pm 18,37$ & 83 \\
Berat 1.000 biji (g)*** & $28,95 \mathrm{a} \pm 2,8$ & $28,16 \mathrm{a} \pm 4,48$ & $30,49 \mathrm{a} \pm 4,32$ & 27,39 \\
Lama Panen (hari)*** & $108,00 \mathrm{a} \pm 0,00$ & $126,80 \mathrm{a} \pm 39,01$ & $109,50 \mathrm{a} \pm 4,24$ & 108,00 \\
\hline
\end{tabular}

Keterangan : (*)Hanya satu tanaman yang berhasil tumbuh hingga panen, (**) Uji ANOVA One-Way, Uji DMRT pada $\alpha=5 \%,(* * *)$ Uji Kruskall-Wallis. Angka yang diikuti huruf yang sama pada baris yang sama menunjukkan hasil yang tidak berbeda nyata $(\mathrm{P}>0,05)$.

Tabel 3. Karakter Agronomi Padi Mutan yang Memiliki Karakter Unik Hasil Mutasi Sinar Gama

\begin{tabular}{ccccccccc}
\hline Mutan & $\begin{array}{c}\text { Panjang } \\
\text { Tanaman } \\
(\mathrm{cm})\end{array}$ & $\begin{array}{c}\text { Jumlah } \\
\text { Gabah Isi } \\
(\mathrm{biji})\end{array}$ & $\begin{array}{c}\text { Jumlah } \\
\text { Gabah } \\
\text { Kosong }\end{array}$ & $\begin{array}{c}\text { Persentase } \\
\text { Gabah Isi } \\
(\%)\end{array}$ & $\begin{array}{c}\text { Berat } \\
100 \text { biji } \\
(\mathrm{g})\end{array}$ & $\begin{array}{c}\text { Lama } \\
\text { Panen } \\
(\text { hari })\end{array}$ & $\begin{array}{c}\text { Jumlah } \\
\text { Anakan }\end{array}$ & $\begin{array}{c}\text { Jumlah } \\
\text { Anakan } \\
\text { Produktif }\end{array}$ \\
\hline A3 & 112 & 35 & 92 & 27,56 & - & 84 & 9 & 4 \\
C6 & 150 & 1044 & 208 & 83,39 & 2,74 & 108 & 10 & 6 \\
Kontrol & 152 & 183 & 378 & 32,62 & 3,21 & 108 & 8 & 6 \\
\hline
\end{tabular}

Keterangan : Kode A menunjukkan tanaman tersebut hasil radiasi 100 gy; dan kode C menunjukkan tanaman tersebut hasil radiasi $400 \mathrm{gy}$

Tabel 4. Kadar Klorofil Padi Merah Mutan Cv. Barak Cenana terhadap Wild Type

\begin{tabular}{cccc}
\hline Parameter & Klorofil a $(\mathrm{mg} / \mathrm{g})$ & Klorofil $\mathrm{b}(\mathrm{mg} / \mathrm{g})$ & Total $(\mathrm{mg} / \mathrm{g})$ \\
\hline Wild Type & $1,90 \mathrm{a} \pm 0,10$ & $0,33 \mathrm{a} \pm 0,33$ & $2,23 \mathrm{a} \pm 0,10$ \\
A3 & $2,83 \mathrm{~b} \pm 0,03$ & $0.69 \mathrm{~b} \pm 0,69$ & $3,52 \mathrm{~b} \pm 0.11$ \\
C6 & $3,25 \mathrm{c} \pm 0,03$ & $1,07 \mathrm{c} \pm 1,06$ & $4,32 \mathrm{c} \pm 0.17$ \\
\hline
\end{tabular}

Keterangan: Uji ANOVA One-Way pada $\alpha=5 \%$, Uji DMRT pada $\alpha=5 \%$. Angka yang diikuti huruf yang sama pada kolom yang sama menunjukkan hasil yang tidak berbeda nyata $(\mathrm{P}>0,05)$. 


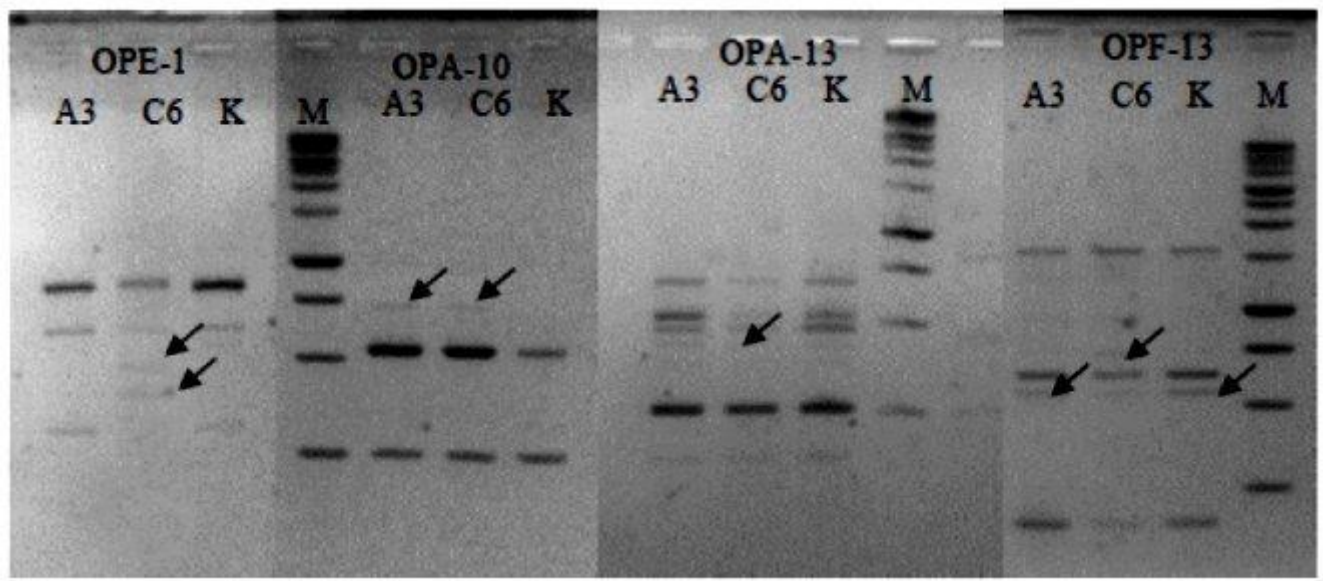

Gambar 3. Perbandingan Hasil RAPD DNA Padi Mutan dengan Karakter Unik Menggunakan Primer OPE-1, OPA-10, OPA-13, dan OPF-13. Keterangan : Tanda panah menunjukkan perbedaan, (A3) mutan 100 gy; (C6) mutan 400 gy, dan (K) Wild-type

\section{Profil Polimorfisme Padi Merah Mutan Cv. Barak Cenana}

Analisa RAPD dilakukan untuk mengkonfirmasi mutasi yang terjadi pada individu mutan $\mathrm{A} 3$ dan $\mathrm{C} 6$ menggunakan 4 jenis primer RAPD yaitu OPA 10, OPA 13, OPE 01dan OPF 13. Hasil RAPD menunjukkan terjadi amplifikasi menghasilkan produk berupa pola pita pada gel. Munculnya pita baru maupun hilangnya pita terjadi pada individu mutan A3 dan C6. Berdasarkan hasil RAPD yang menunjukkan adanya tambahan pita baru maupun hilangnya pita pada mutan A3 dan C6 menghasilkan polimorfisme yang mengindikasikan terjadinya mutasi pada mutan padi Barak Cenana. Nilai PIC menunjukkan kemampuan dari primer tersebut untuk menunjukkan polimorfisme diantara individu sampel dengan nilai maksimal 0.5 dengan klasifikasi keinformatifan yaitu rendah ( 0 $0,10)$, medium $(0,10-0,25)$, tinggi $(0,30-0,40)$, dan sangat tinggi $(0,40-0,50)$. Berdasarkan hasil bahwa nilai PIC tertinggi terdapat pada primer OPE 01 yang menghasilkan pita polimorise paling banyak.

Tabel 5. PIC Value Primer RAPD

\begin{tabular}{cccc}
\hline Mutan & PIC & Total Pita & $\begin{array}{c}\text { Jumlah Pita } \\
\text { Polimorfisme }\end{array}$ \\
\hline OPA-10 & 0.15 & 8 & 1 \\
OPA-13 & 0.11 & 17 & 1 \\
OPE-01 & 0.43 & 9 & 3 \\
OPF-13 & 0.25 & 10 & 1 \\
\hline
\end{tabular}

Hasil RAPD menggunakan primer OPE-1 selanjutnya dilakukan analisa similarity index dengan metode jaccard untuk mengetahui kekerabatan antara mutan dengan Wild Type. Mutan C6 memiliki perbedaan yang lebih besar dengan Wild Type yaitu 0.33 dibandingkan dengan mutan A3. Mutan A3 memiliki Similarity Index sebesar 0.75 dan mutan C6 sebesar 0.33 terhadap Wild Type, sedangkan anatra mutan A3 dan C6 memiliki Similarity Index sebesar 0.40.

\section{Perkecambahan Padi Merah Cv. Barak Cenana}

Pertumbuhan kecambah padi Barak Cenana menurun seiring dengan meningkatnya dosis radiasi sinar gamma (Gambar 1). Hal yang sama terjadi pada padi hitam lokal cempo ireng, cempo melik, dan melik dan padi dataran rendah FARO 44, dan FARO 60 didapati tunas dari kecambah padi yang tumbuh semakin pendek seiring penambahan dosis radiasi (Yuwono dan Sutoyo, 2017; Jiya et al., 2018). Sinar gamma menyebabkan terjadinya kerusakakan DNA dan dapat berakibat pada terganggunya sintesis protein sehingga mempengaruhi sintesis protein, keseimbangan hormon, pertukaran gas pada daun, pertukaran air, dan aktivitas enzim yang memungkinkan terjadinya hambatan/perubahan fisiologi, morfologi, pertumbuhan dan perkembangan tanaman (Dehpour et al., 2011). Dosis radiasi 200 gy merupakan dosis radiasi yang tepat untuk melakukan mutasi, karena dosis tersebut adalah LD50 yang berarti pada dosis tersebut tanaman tersebut dapat tumbuh dan 
berkembang seperti kondisi normalnya (Oladosu et al., 2016, Ramchander et al., 2015, dan Kadhimi et al., 2016).

\section{Karakter Fenotipik Padi Merah Mutan Cv. Barak Cenana}

Padi hasil radiasi memiliki kesintasan yang rendah yaitu hanya 14 tanaman yang bertahan hingga usia panen. Salah satu faktor kemungkinan yang memicu rendahnya kesintasan padi yang diradiasi adalah kerusakan fungsi sel yang diakibatkan oleh kerusakan DNA sehingga memicu kematian sel (Jankowicz et al., 2017). Secara umum dari hasil pengamatan secara kelompok ditemukan bahwa tidak terlihat pengaruh terhadap fenotip, tetapi pada pengamatan secara individu teramati adanya individu dengan karakter yang unik. Pada penelitian yang dilakukan Ashraf et al. (2003) menunjukkan padi Basmati 370, Basmati Pak, Basmati 385, Super Basmati, dan Basmati 2000 yang teradiasi sinar gama memiliki panjang tanaman yang semakin pendek dan produktivitas yang rendah seiring dengan bertambahnya dosis radiasi yang diberikan dan pada kondisi penanaman in vitro dan ex vitro. Begitu pula dengan padi hitam lokal Cempo Ireng yang teradiasi sinar gama menunjukkan tanaman yang tumbuh semakin pendek dengan bertambahnya dosis radiasi (Yuwono dan Suyoto, 2017). Pada penelitian lain diperoleh generasi M3 padi Mentik Susu yang lebih pendek, produktivitas lebih besar, dan waktu panen yang lebih cepat dibandingkan dengan Wild Type, yaitu dengan diradiasi pada dosis 200 gy (Rachmawati et al., 2019). Berbeda dengan penelitian yang di lakukan Jiya et al pada tahun 2018 dimana padi FARO 44 dan 60 memiliki waktu panen lebih lama seiring dengan semakin besar dosis radiasi yang diberikan.

Pada pengamatan individu ditemukan individu yang memiliki karakter unik/ekstrim pada individu mutan A3 yaitu waktu panen yang lebih singkat dengan tinggi tanaman yang lebih pendek dan individu mutan C6 yaitu jumlah gabah isi yang lebih banyak dibandingkan dengan Wild Type. Mutan A3 memiliki kadar klorofil yang lebih banyak dari pada kontrol, tetapi produktivitas-nya tidak mengalami peningkatan. Selain itu nampak persentase gabah isi yang relatif tidak terlalu berbeda dengan Wild Type. Hal ini mengindikasikan bahwa tanaman tersebut mampu mengisi gabahnya dengan cukup baik, hanya saja produktivitasnya rendah akibat pembentukan malai yang buruk. Kemungkinan ada gangguan pada sintesis protein, dan aktivitas enzim atau transpor hasil fotosintesis yang kurang dari daun menuju daerah malai akibat fisiologi/morfologi tanaman berubah yang memungkinkan terjadinya hambatan pada pembentukan malai (Dehpour et al., 2011; dan Joy et al., n.d.).

Mutan C6 memiliki kadar klorofil yang tinggi yang kemungkinan dapat meningkatkan laju fotosintesis dari tanaman sehingga hasil panen yang diperoleh lebih baik ditandai dengan jumlah gabah isi yang banyak. Fenomena kadar klorofil yang lebih banyak dari pada Wild Type kemungkinan disebabkan oleh reaksi cekaman oleh sinar gama dimana sesuai dengan penelitian yang dilakukan Meliala dan Soegianto pada tahun 2016 pada padi Gogo dimana mutan yang dihasilkan memiliki kandungan klorofil lebih banyak dibandingkan Wild Type akibat reaksi cekaman radiasi sinar gama. Namun, berkontradiksi dengan penelitian Rajarajan et al. (2014) dimana tidak ada korelasi antara penambahan dosis radiasi terhadap mutasi klorofil pada padi ADT. Selain itu persentase gabah isi dari tanaman C6 nampak sangat tinggi, hal ini disebabkan pengisian malai dan juga pembentukan malai yang sangat baik, sehingga produktivitas dari tanaman ini tinggi apabila dibandingkan dengan Wild Type. Kedua individu ini memiliki sifat argonomis yang lebih baik sehingga diharapkan apabila sifat ini stabil dapat digunakan sebagai sumber eksplan untuk dilakukan pemuliaan lebih lanjut.

\section{Profil Polimorfisme Padi Merah Mutan Cv. Barak Cenana}

Analisa RAPD yang dilakukan dalam penelitian dilakukan untuk mnegetahui perbedaan genetik yang terjadi pada mutan hasil dari induksi mutasi dengan EMS. Hasil RAPD dengan menggunakan 5 jenis primer menghasilkan 6 pita polimorfisme. Selain itu, similarity index mutan dengan Wild Type menunjukkan bahwa mutan A3 memiliki kesamaan sebesar 0.75 yang berarti memiliki kemiripan paling dekat dengan Wild Type dibandingkan dengan mutan C6 sebesar 0.33. Polimorfisme yang terjadi diantara individu mutan A3, mutan C6 dan Wild Type disebabkan 
oleh terjadinya variasi pada pola pita yang dihasilkan akibat dari radiasi sinar gama yang dapat merubah susunan DNA dari mutan, yang kemungkinan besar mutasi berupa delesi DNA baik delesi titik hingga besar dan mengatur ulang DNA secara acak pada DNA (Barakat dan ElSammak, 2011; Tai, 2007; Penna et al., 2012; Dehpour et al., 2011; dan Wu et al., 2005). Variasi pola pita RAPD dihasilkan dari munculnya pita baru pada individu mutan ataupun hilangnya pita pada individu mutan dan Wild Type. Polimorfisme yang muncul pada individu mutan tersebut dapat dikarenakan oleh terjadinya perubahan nukleotida yang mencegah terjadinya amplifikasi oleh primer yang dikarenakan oleh delesi, insersi, substitusi daerah penempelan primer sehingga mengubah ukuran produk (Barakat \& El-Sammak, 2011). Oleh sebab itu, maka metode RAPD yang digunakan dalam penelitian ini dapat mendeteksi adanya polimorfisme atau perbedaan yang terjadi antara mutan dengan Wild Type yang disebabkan oleh variasi genetik akibat dari induksi mutasi dengan mutagen EMS.

\section{Kesimpulan}

Berdasarkan penelitian yang dilakukan diperoleh bahwa perlakuan radiasi dengan sinar gamma pada padi Barak Cenana pada dosis radiasi 400-800 gy memberikan pengaruh negatif terhadap pertumbuhan perkecambahan dan diperoleh 2 mutan hasil mutasi pada dosis radiasi 100 gy dan 400 gy yaitu A3 dan C6 dengan karakter yang lebih baik yaitu tinggi tanaman yang lebih pendek, waktu panen yang lebih singkat dan jumlah gabah isi yang lebih banyak dibandingkan Wild Type. Selain itu, diperolehnya mutan A3 dan C6 ini dapat digunakan untuk memperbanyak plasma nutfah dan untuk memperoleh generasi mutan selanjutnya yang memiliki karakter produktifitas lebih banyak dan tinggi tanaman yang lebih pendek.

\section{Ucapan terima kasih}

Penelitian ini didanai oleh Kolaborasi Riset dan Hibah Riset Publikasi International dari DIKTI-Kementerian Riset dan Teknologi Indonesia. Semua percobaan dilakukan di Fakultas Teknobiologi Universitas Surabaya.

\section{Referensi}

Aprida \& Yuwono, S. S. (2017). Phenotype of M2 Generation of Mutant Black Rice (Oryza sativa L). International Journal of Agriculture \& Environmental Science, 4(5):1-3. Doi: 10.14445/23942568/ijaesv4i5p101.

Barner, J. D., Balaguer, L., Manrique, E., Elvira, S., \& Davison, A. W. (1992). A reapraisal of the use of DMSO for extraction and determination of chlorophylls $a$ and $b$ in lichens and higher plants. Environtmental and Experimental Botany, 32(2):85-100. DOI: $\quad$ https://doi.org/10.1016/00988472(92)900-Y

Bhuiyan, M.S.H., Malek, M., A., Bhuiyan, S., H., Islam, M., \& Hassan, A. B. A. (2019). Mutation determination of rice by using RAPD primers. Int. J. Agril. Res. Innov. Tech. 9(1): 1-7. DOI: http://dx.doi.org/10.3329/ijarit.v9i1

Dehpour, A. A. Gholampour, M., Rahdary, P., Talubaghi, M. R. J., \& Hamdi, S. M. M. (2011). Effect of gamma irradiation and salt stress on germination, callus, protein and proline in rice (Oryza sativa L.) Determination of proline content. Iranian Journal of Plant Physiology, 1(4): 251256. Available at: http://www.iausaveh.ac.ir/Files/Journal/2011-1225_01.46.54_5.pdf.

Deshmukh, V. P., Thakare, P. V., Chaudhari, U. S., \& Gawande, P. A. (2007). A simple method for isolation of genomic DNA from fresh and dry leaves of Terminalia arjuna (Roxb.) Wight and Argot'. Electronic Journal of Biotechnology, 10(3):468-472. DOI: 10.2225/vol10-issue3-fulltext-5

Gill, S. S., Anjum, N. A., Gill, R., Jha, M., \& Tuteja, N. (2015). DNA damage and repair in plants under ultraviolet and ionizing radiations. Scientific World Journal, 5-7. https://doi.org/10.1155/2015/250158 
Gunaratne, A., Wu, K., Li, D., Bentota, A., Corke, H. \& Cai, Y. Z. (2013). Antioxidant activity and nutritional quality of traditional red-grained rice varieties containing proanthocyanidins. Food Chem, 138(2-3): 1153-1161. doi 10.1016/j.foodchem.2012.11.129.

Hammer, O., Harper, D., \& Ryan, P. (2001). PAST: Paleontological Statistics Software Package for Education and Data Analysis. Palaeontologia Elctronica, 4:1-9. http://palaeo-electronica.org

Jankowicz-Cieslak, J., Mba, C., \& Till, B. J. (2016). Mutagenesis for crop breeding and functional genomics. Biotechnologies for Plant Mutation Breeding: Protocols. https://doi.org/10.1007/978-3-319-45021$\underline{61}$

Kadhimi, A. A., Alhasnawi, A. N., Isahak, A., Ashraf, M. F., Mohamad, A., Wan, \& Zain, C. M. (2016). Gamma radiosensitivity study on MRQ74 and MR269, two elite varieties of rice (Oryza Sativa L.). Life Science Journal, 13(2). https://doi.org/10.7537/marslsj13021614

Kim, J. H., Ryu, T. H., Lee, S. S., Lee, S., \& Chung, B. Y. (2019). Ionizing radiation manifesting DNA damage response in plants: An overview of DNA damage signaling and repair mechanisms in plants. Plant Science, 278(September 2018), 4453.

https://doi.org/10.1016/j.plantsci.2018.10. $\underline{013}$

Li, S., Zheng, Y. chao, Cui, H. rui, Fu, H. wei, Shu, Q. yao, \& Huang, J. zhong. (2016). Frequency and type of inheritable mutations induced by $\gamma$ rays in rice as revealed by whole genome sequencing. Journal of Zhejiang University: Science B, 17(12):905-915. https://doi.org/10.1631/jzus.B1600125

Manova, V., \& Gruszka, D. (2015). DNA damage and repair in plants - From models to crops. Frontiers in Plant Science, 6: 1-
26.

https://doi.org/10.3389/fpls.2015.00885

Masood, S. A. et al. (2015). An overview of genetic improvement for drought tolerance in rice (Oryza sativa L.). Life Science, 12(3):63-70.

http://www.lifesciencesite.com

Masruroh, F., Samanhudi, Sulanjari, \& Yunus, A. (2016). Improvement of Rice (Oryza sativa L.) var. Ciherang and Cempo Ireng Productivity Using Gamma Irradiation. Journal of Agricultural Sciences and Tehnology B. 289-294. doi: 10.17265/2161-6264/2016.05.001

Meliala, J. H. S., Basuki, N. \& Soegianto, A. (2017). Pengaruh iradiasi sinar gama terhadap perubahan fenotipik tanaman padi gogo (Oryza sativa L.). Jurnal Produksi Tanaman, 4(7):585-594. http://protan.studentjournal.ub.ac.id

Mohanty, S. (2013). Trends in global rice consumption. Available at: http://irri.org/rice-today/trends-in-globalrice-consumption (Diakses: 15 Juli 2020).

Naeem, M., Ghouri, F., Sahid, M.Q., eat al. (2015). Genetic diversity in mutated and non-mutated rice varieties. Genetics and Molecular Research, 14(4):17109-17123. DOI: 10.4238/2015.December.16.11.

Oladosu, Y., Rafii, M. Y., Abdullah, N., Hussin, G., Ramli, A., Rahim, H. A. \& Usman, M. (2016). Principle and application of plant mutagenesis in crop improvement: A review. Biotechnology and Biotechnological Equipment, 30(1): 1-16. https://doi.org/10.1080/13102818.2015.1 $\underline{087333}$

Rachmawati, D. et al. (2019). Selection of short stem Mentik Susu rice M3 from gamma ray irradiation. IOP Conference Series: Earth and Environmental Science, 250(1). DOI: $10.1088 / 1755-1315 / 250 / 1 / 012020$.

Rajarajan, D., R.Saraswathi, D. Sassikumar, \& S.K Ganesh. (2014). Fixation Of Lethal 
Dose And Effect Of Ethyl Methane Sulfonate Induced Mutagenesis In Rice $\operatorname{Adt}(\mathrm{R})$ 47. Life Sciences Leaflets, 57: 6572. Diakses dari http://lifesciencesleaflets.ning.com/.

Sidler, C., Li, D., Kovalchuk, O., \& Kovalchuk, I. (2015). Development-Dependent Expression of DNA Repair Genes and Epigenetic Regulators in Arabidopsis Plants Exposed to Ionizing Radiation. Radiation Research, 183(2): 219. https://doi.org/10.1667/rr13840.1

Silitonga, T.S. (2015). Katalog SDG tanaman pangan tahun 2015. Balai Besar Penelitian dan Pengembangan Bioteknologi dan Sumberdaya Genetik Pertanian, Bogor. (Diakses: 16 Juli 2020)

Tai, T. H. (2007). Induced mutations in rice (Oryza sativa L.). Israel Journal of Plant Sciences, 55(2): 137-145. DOI: 10.1560/IJPS.55.2.137.

USDA (2013). Production, Supply, and Distribution (PSD) Online. Available at: https://www.fas.usda.gov/databases/produ ction-supply-and-distribution-online-psd (Diakses: 15 Juli 2020).

Wellburn, A. R. (1994). The Spectral Determination of Chlorophyll $\mathrm{a}$ and $\mathrm{b}$, as well as Total Carotenoids, Using Various Solvents with Spectrophotometers of Different Resolution. Journal of Plant Physiology, 144(3):307-313. DOI: https://doi.org/10.1016/S01761617(11)81192-2

Widarta, I. W. ., Nocianitri, K. A. \& Sari, L. P. I. P. (2013). 'Ekstraksi Komponen Bioaktif Bekatul Beras Lokal Dengan Beberapa Jenis Pelarut', Jurnal Aplikasi Tekologi Pangan, 2(2), pp. 75-79.

Yuwono, S. S. et al. (2017) 'Early Growth Performance Some Vaierties of Black Rice (Oryza Sativa L.) Irradiated Using Gamma', 10(2), pp. 145-153.
Zhang, M. W., Zhang, R. F., Zhang, F. X. \& Liu, R. H. (2010). 'Phenolic profiles and antioxidant activity of black rice bran of different commercially available varieties', Journal of Agricultural and Food Chemistry, 58, pp. 7580-7587.

Ghazali M., Husna H. \& Sukiman. (2018). Diversitas dan Karakteristik Alga Merah (Rhodophyta) pada Akar Mangrove di Teluk Serewe Kabupaten Lombok Timur. Jurnal Biologi Tropis, 18 (1): 80-90. DOI: http://dx.doi.org/10.29303/jbt.v18i1.732 